\title{
Knockdown of Fibrous Sheath Interacting Protein I Expression Reduces Bladder Urothelial Carcinoma Cell Proliferation and Induces Apoptosis via Inhibition of the PI3K/AKT Pathway [Retraction]
}

\author{
Sun M, Chen Z, Tan S, Liu C, Zhao W. Onco Targets Ther. 2018;11:1961-1971.
}

The Editor and Publisher of OncoTargets and Therapy wish to retract the published article. Concerns were raised regarding alleged image duplication in Figure 4C. Specifically:

- Figure 4C, panel BC has been duplicated with Figure 4C, panel NC with the image having been flipped and rotated.

The authors responded to our queries but were unable to provide a satisfactory explanation for the alleged image duplication or adequate raw data for their study. The findings of the article were deemed invalid and the Editor requested for the article to be retracted.

Our decision-making was informed by our policy on publishing ethics and integrity and the COPE guidelines on retraction.

The retracted article will remain online to maintain the scholarly record, but it will be digitally watermarked on each page as "Retracted".

\section{Publish your work in this journal}

OncoTargets and Therapy is an international, peer-reviewed, open access journal focusing on the pathological basis of all cancers, potential targets for therapy and treatment protocols employed to improve the management of cancer patients. The journal also focuses on the impact of management programs and new therapeutic agents and protocols on patient perspectives such as quality of life, adherence and satisfaction. The manuscript management system is completely online and includes a very quick and fair peer-review system, which is all easy to use. Visit http://www.dovepress.com/testimonials.php to read real quotes from published authors. 